\title{
Our experience with pediatric treatment of chronic radial head dislocation
}

\author{
I.Yu. Khodzhanov ${ }^{1}$, Yu.P. Soldatov ${ }^{2}$, G.Dz. Baiimbetov ${ }^{1}$, U.A. Edilov ${ }^{1}$ \\ ${ }^{1}$ Republican Specialized Scientific and Practical Medical Center of Traumatology and Orthopedics, Tashkent, the Republic of Uzbekistan \\ ${ }^{2}$ Ilizarov National Medical Research Centre for Traumatology and Orthopedics, Kurgan, Russian Federation
}

\begin{abstract}
Objective Improve the effectiveness of pediatric treatment of chronic radial head dislocations (CRHD). Material and methods The review included 100 pediatric patients aged 2-18 years treated for CRHD between 2005 and 2019. Patients underwent physical examination, radiological (conventional radiography, US, MRI, MSCT) evaluation and statistical analysis was performed. Patients were divided into two groups. A major group consisted of $33(33 \%)$ patients who were treated with new bone and plasty procedures including open reduction of the radial head (ORRH), plasty of the annular ligament with $\mathrm{m}$. anconeus flap and fixation with the plaster cast; osteotomy of the proximal ulna and ulnar realignment with the Ilizarov external fixation. Outcomes were retrospectively compared with $67(67.0 \%)$ control patients treated with different classical techniques including ORRH, radial head fixation with wires, polyethyleneterephthalate band or the remnants of the annular ligament, with/without ulnar osteotomy. Anatomical and functional results of treatment were evaluated at a short (up to one year) and long term (over one year) after frame removal using modified Mattis-Lyuboshitz-Shwarzberg grading scale. Results Comparative analysis of outcomes of surgical management at a short- and long term in both groups showed that the percentage of good results was 1.5 times higher in the major group. A table of differentiated indications to pediatric treatment of CRHD was devised based on the findings. Conclusion Biomechanical articular parameters appear to deteriorate over time following radial head dislocation and can result in radial head deformity, malaligned and shortened ulna. Pediatric treatment is supposed to be differentiated depending on time of injury, patient's age, anatomical and radiological manifestations of the joint. Operative pediatric treatment of CRHD involving bone and plasty procedures can provide good internal fixation preventing recurrence.
\end{abstract}

Keywords: chronic dislocation, radial head, surgical treatment, osteotomy, Ilizarov external fixation, bone and plasty procedure, outcome

\section{INTRODUCTION}

Elbow fractures are among the most common traumatic injuries in the paediatric population and associated with a high complication rate. Chronic radial head dislocations (CRHD) represent approximately $1.9-2.7 \%$ of elbow injuries [1] and $86 \%$ of paediatric traumatic elbow dislocations [2-4]. Late detection of dislocations of the radial head after forearm fractures often leads to the development of complications including elbow contracture and valgus deformity, neurotrophic changes in the forearm bones [5]. Treatment of patients with CRHD is a challenge due to the risk of recurrent dislocation even after surgical interventions [6-8]. With a wide variety of treatment modalities and different scientific schools, long-term results are not always satisfactory due to surgical annular ligament reconstruction that can lead to recurrence $[9,-11]$. The treatment of neglected radial head dislocation in children is still open to controversy [12-14].
The study was performed in accordance with ethical principles for medical research involving human subjects stated in the Declaration of Helsinki developed by the World Medical Association, Order of the Ministry of Health of the RF dtd 19th June 2003 No. 266 on Clinical Practice Guidelines in the Russian Federation and GOST R ISO 14155-1-2008 Clinical investigation of medical devices for human subjects. Part 1. General requirements. The study received a favorable opinion from the relevant research ethics committee of the Russian Ilizarov Scientific Center for Restorative Traumatology and Orthopaedics Ministry of Health of the Russian Federation. The data obtained were summarized as means \pm standard deviations.

The purpose of the study was to improve the effectiveness of pediatric treatment of chronic radial head dislocations (CRHD).

\section{MATERIAL AND METHODS}

The review included 100 pediatric patients aged 2-18 years treated for CRHD between 2005 and 2019. Patients underwent physical examination, radiological (conventional radiography, US, MRI, MSCT) evaluation and statistical analysis was performed. Patients were divided into two groups. A major group 
consisted of $33(33 \%)$ patients who were treated with new bone and plasty procedures. Outcomes were retrospectively compared with $67(67.0 \%)$ control patients treated with different classical techniques. The main group consisted of $19(57.6 \%)$ male and $14(42.4 \%)$ female patients. The patients' ages in the main group were $3-7$ years $(\mathrm{n}=4 ; 12.1 \%), 8-11$ years $(\mathrm{n}=8 ; 24.2 \%), 12-15$ years $(\mathrm{n}=5 ; 15.2 \%), 16-$ 18 years $(\mathrm{n}=16 ; 48.5 \%)$. There were $39(58.2 \%)$ male and $28(41.8 \%)$ female patients in the control group aged $3-7$ years $(\mathrm{n}=16 ; 23.9 \%), 8-11$ years $(\mathrm{n}=36 ; 53.8 \%), 12-15$ years $(\mathrm{n}=8 ; 11.9 \%), 16$ 18 years $(\mathrm{n}=7 ; 10.4 \%)$. Time from injury to surgery in both groups were two weeks $(n=4), 2$ to 4 weeks $(\mathrm{n}=15), 1$ month to 6 months ( $\mathrm{n}=21), 6$ to 12 months $(\mathrm{n}=33), 1$ year to 4 years $(\mathrm{n}=27)$.

Surgical treatment of $67(67.0 \%)$ patients of the control retrospective group including open reduction of the radial head (ORRH), radial head fixation with wires, polyethyleneterephthalate band or the remnants of the annular ligament, with/without ulnar osteotomy consisted of (1) ORRH with transarticular wire fixation and elbow immobilized with plaster cast $(\mathrm{n}=5 ; 7.5 \%)$; (2) ORRH with radial head fixed with polyethyleneterephthalate band and elbow immobilized with plaster cast $(n=3 ; 4.5 \%)$; (3) ORRH with transarticular fixation, oblique proximal ulnar osteotomy with wire fixation and elbow immobilized with plaster cast/Ter-EgiazarovShaklychev procedure ( $\mathrm{n}=16 ; 23.8 \%$ ); (4) ORRH with transarticular fixation, oblique proximal ulnar osteotomy with wire fixation ( $\mathrm{n}=12 ; 17.9 \%)$; (5) ORRH with internal fixation using the remnants of the annular ligament, transarticular wire fixation $(\mathrm{n}=17$; $25.4 \%$ ); (6) ORRH with internal fixation using the remnants of the annular ligament, oblique proximal ulnar osteotomy with wire fixation $(\mathrm{n}=14 ; 20.9 \%)$.

Patients of the main group ( $\mathrm{n}=33 ; 33 \%)$ were treated with new techniques developed to stabilize the radial head including ORRH, plasty of the annular ligament with $\mathrm{m}$. anconeus flap and fixation with the plaster cast (patent specification № IAP 20180477 of 09.10.2018 AIS Ruz) performed for 18 cases (54.5\%). Four patients who sustained injury more than a year ago and had ulnar deformity at the consolidated level underwent additional osteotomy of the proximal ulna fixed with intramedullary wire for easier radial head reduction.

The technique used consisted of (Fig. 1) an incision made over the posterior lateral aspect of the elbow joint with the mid portion being at the level of the radial neck with a transition to the distal humerus.
With the fibrous tissue bands removed and the muscles retracted, the radial head was reduced with the anconeus muscle being mobilized and the lateral epicondyle exposed to resect the proximal portion of the $\mathrm{m}$. anconeus tendon at the site of attachment to the lateral condyle. Then the soft tissues were mobilized to the muscles to obtain a tendon-muscle flap of about $4 \mathrm{~cm}$ long reinforced with silk threads. The proximal radius was mobilized at the neck in an acute and blunt way. The radial neck was fixed with the tendon-muscle flap in a loop manner with the end of the flap being attached to the ulna at the base reaching the level of the radial notch. Although the flap loop was securely fixed, the radial head was transarticularly fixed for 2 weeks using a Kirschner wire for appropriate flap adaptation. The K-wire and the sutures were removed after two weeks to allow passive flexion, extension and rotation followed by active physical therapy of the elbow after another two weeks.

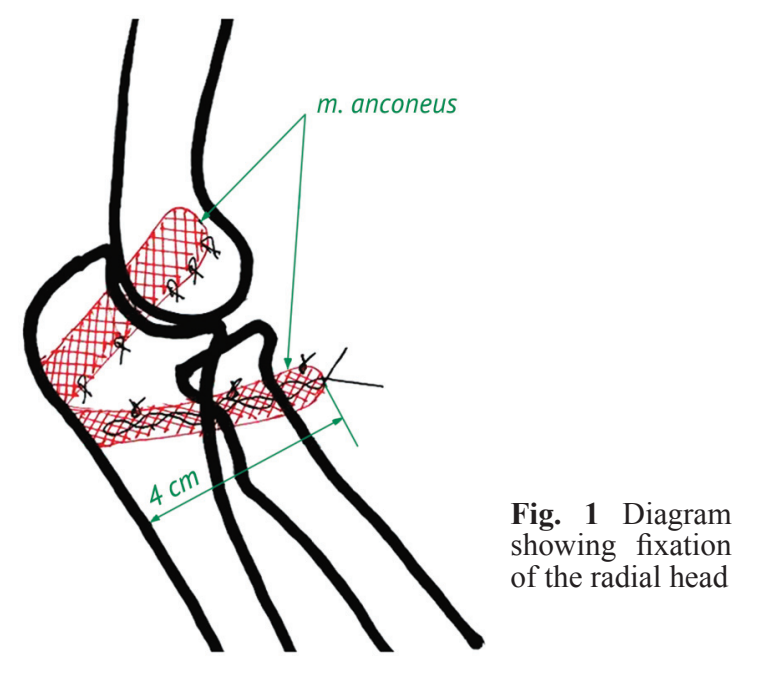

Fifteen $(45.5 \%)$ children of the main group aged 14-18 years with a disease duration of more than one year who developed deformity and shortening of the ulna due to the Monteggia fracture underwent osteotomy of the proximal ulna for lengthening, realignment and gradual reduction of the radial head using the Ilizarov external fixation (application $\mathrm{N}$ 2002129070/14 RF, MKI7 A 61 B 17/56 Method of treatment of chronic dislocation of the radial head and device for its implementation /Yu. P. Soldatov, V. D. Makushin (RF). Application issued 30.10.02). The Ilizarov frame consisted of three rings with with wires placed in the proximal, middle and distal forearm. The rings were connected by rods with hinges mounted to the proximal ring placed obliquely for correction. The distal wires were driven in the radius and the ulna while the ulna was fixed with wires driven proximally and in the middle third (Fig. 2). 

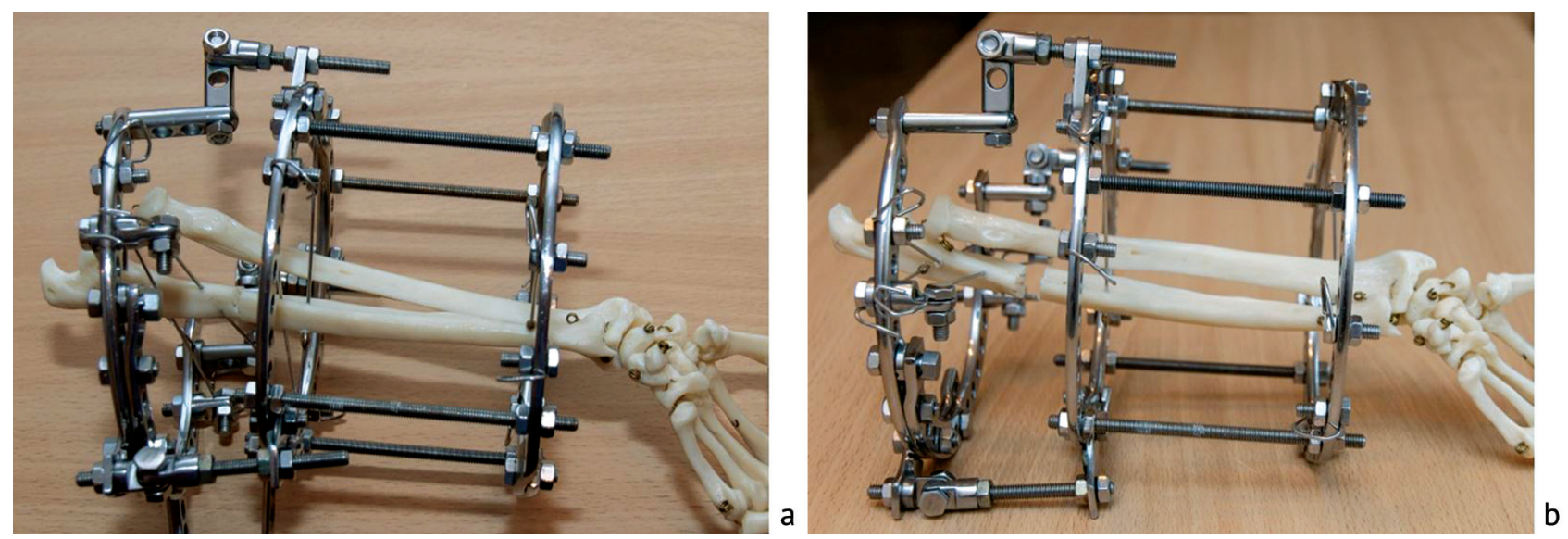

Fig. 2 Appearance of the Ilizarov frame assembled for gradual reduction of the CRHD with the proximal ulnar osteotomy (a) perioperatively; (b) with ulnar lengthening, realignment and gradual reduction performed

After five-to-six-day latency, distraction was commenced at the rate of one $\mathrm{mm}$ per day for ulnar lengthening. With the radial head being brought down to the level of the coronoid process of the ulna within 6-10 days, distraction was carried out solely with the rods located on the concave side (in this case, with the posterior rods of the Ilizarov frame). The radial head was brought down and centered relative to the capitated prominence of the humerus. Ulna was realigned until the radial head was completely centered. A 20-25-minute training session with maximum flexion was performed for the joint three time per day during ulnar lengthening. Ulnar distraction and realignment was produced for
$22.5 \pm 3.5$ days. Ulnar fixation with the frame on lasted $49.0 \pm 3.3$ days. With the Ilizarov device dismantled, patients were encouraged to exercise the joint for 2-3 weeks using the own muscle strength first, and then, a gradually increasing load (one to three $\mathrm{kg}$ ) on the operated limb. Patients were allowed to produce a full functional load on the limb after 3-4 months. Anatomical and functional results of treatment were evaluated at a short (up to one year) and long term (over one year) after frame removal using modified MattisLyuboshitz-Shwarzberg grading scale [15] (Table 1).

Outcomes scored 14 to 21 were rated as good, 8 to 13 as fair and 0 to 8 as poor.

Table 1

Short- and long-term outcomes of CRHD patients

\begin{tabular}{|l|c|c|c|c|}
\hline Anatomic and functional parameters & \multicolumn{4}{|c|}{ Characterization of manifestations and scoring } \\
\hline Pain & none & $\begin{array}{c}\text { short-term, mild pain } \\
\text { with load }\end{array}$ & $\begin{array}{c}\text { short-term, moderate } \\
\text { pain with load }\end{array}$ & $\begin{array}{c}\text { severe pain with load } \\
\text { or regularly }\end{array}$ \\
\hline $\begin{array}{l}\text { Forearm and wrist flexor/extensor } \\
\text { muscles strength }\end{array}$ & $\begin{array}{c}\text { no changes or } \\
\text { increased }\end{array}$ & $\begin{array}{c}\text { slightly decreased } \\
\text { (up to 5 \%) }\end{array}$ & $\begin{array}{c}\text { moderately decreased } \\
\text { (up to 15\% or by 1 score } \\
\text { according to V.O.Marx) }\end{array}$ & $\begin{array}{c}\text { severely decreased } \\
\text { (more than } 15 \%)\end{array}$ \\
\hline Neurovascular disorders & none & $\begin{array}{c}\text { no neuropathy, } \\
\text { moderately swollen } \\
\text { (up to 1 cm) }\end{array}$ & $\begin{array}{c}\text { no neuropathy, swelling } \\
\text { of 2 cm }\end{array}$ & $\begin{array}{c}\text { neuropathy, swelling } \\
\text { of more than } 2 \text { cm }\end{array}$ \\
\hline OA & $\begin{array}{c}\text { absent or positive } \\
\text { dynamics }\end{array}$ & pre-op signs & slightly aggravated & progressing \\
\hline Elbow flexion/extension & increased & no changes & decreased to 15 & $\begin{array}{c}\text { decreased to } 15^{0} \text { and } \\
\text { over }\end{array}$ \\
\hline Ability to work & regained & retained & low & disability \\
\hline $\begin{array}{l}\text { Index of increase in ROM (II) II = IE/ED, } \\
\text { where IE, increased angle of extension; } \\
\text { ED, extension deficiency }\end{array}$ & 1.0 & $0.75-0.9$ & $0.5-0.7$ & less than 0.5 \\
\hline Scores & 3 & 2 & 1 & 0 \\
\hline
\end{tabular}

\section{RESULTS}

Results of treatment were rated as good in 58.2\% of control patients at a short- and long-term followup (Table 2). Persistent flexion-extension and rotation contractures that failed to respond to rehabilitation were noted in $25.4 \%$ of patients whose outcomes were rated as fair at a short and long term. The complication could be ascribed to prolonged immobilization and delayed rehabilitation. Recurrence occurred in $16.4 \%$ of patients who underwent no ulnar reconstruction with resultant poor outcome. No poor outcomes/ recurrence were observed among 14 patients who underwent ORRH, oblique proximal ulnar osteotomy, internal fixation using the remnants of the annular ligament and Ilizarov external fixation. 
Comparative outcomes of CRHD patients treated with different surgical modalities

\begin{tabular}{|c|c|c|c|c|c|c|}
\hline \multirow{3}{*}{ Type of surgeries performed for controls } & \multicolumn{6}{|c|}{ Outcomes in control group } \\
\hline & \multicolumn{2}{|c|}{ good } & \multicolumn{2}{|c|}{ fair } & \multicolumn{2}{|c|}{ poor } \\
\hline & short-term & long-term & short-term & long-term & short-term & long-term \\
\hline $\begin{array}{l}\text { ORRH with transarticular wire fixation and elbow } \\
\text { immobilized with plaster cast }(n=5 ; 7.5 \%)\end{array}$ & 2 & 2 & - & - & 3 & 3 \\
\hline $\begin{array}{l}\text { ORRH with radial head fixed with } \\
\text { polyethyleneterephthalate band and elbow } \\
\text { immobilized with plaster cast }(n=3 ; 4.5 \%)\end{array}$ & - & - & 2 & 2 & 1 & 1 \\
\hline $\begin{array}{l}\text { ORRH with transarticular fixation, oblique } \\
\text { proximal ulnar osteotomy with wire fixation } \\
\text { and elbow immobilized with plaster cast/Ter- } \\
\text { Egiazarov-Shaklychev procedure }(\mathrm{n}=16 ; 23.8 \%)\end{array}$ & 9 & 9 & 5 & 5 & 2 & 2 \\
\hline $\begin{array}{l}\text { ORRH with transarticular fixation, oblique } \\
\text { proximal ulnar osteotomy with wire fixation } \\
(\mathrm{n}=12 ; 17.9 \%)\end{array}$ & 5 & 5 & 4 & 4 & 3 & 3 \\
\hline $\begin{array}{l}\text { ORRH with internal fixation using the remnants of } \\
\text { the annular ligament, transarticular wire fixation } \\
(\mathrm{n}=17 ; 25.4 \%)\end{array}$ & 12 & 12 & 3 & 3 & 2 & 2 \\
\hline $\begin{array}{l}\text { ORRH with internal fixation using the remnants } \\
\text { of the annular ligament, oblique proximal ulnar } \\
\text { osteotomy with wire fixation }(n=14 ; 20.9 \%)\end{array}$ & 11 & 11 & 3 & 3 & - & - \\
\hline TOTAL (controls, $\mathrm{n}=67$ ) & $39(58.2 \%)$ & $39(58.2 \%)$ & $17(25.4 \%)$ & $17(25.4 \%)$ & $11(16.4 \%)$ & $11(16.4 \%)$ \\
\hline $\begin{array}{l}\text { Type of surgeries performed for patients of the } \\
\text { main group }\end{array}$ & \multicolumn{6}{|c|}{ Outcomes in the main group } \\
\hline $\begin{array}{l}\text { ORRH, plasty of the annular ligament with } \mathrm{m} \text {. } \\
\text { anconeus flap and fixation with the plaster cast } \\
(\mathrm{n}=14)\end{array}$ & 14 & 14 & - & - & - & - \\
\hline $\begin{array}{l}\text { ORRH, plasty of the annular ligament with } m \text {. } \\
\text { anconeus flap, fixation of the radial head with } \\
\text { transarticular wire, oblique proximal ulnar } \\
\text { osteotomy and wire fixation }(n=4)\end{array}$ & 2 & 2 & 2 & 2 & - & - \\
\hline $\begin{array}{l}\text { Ulnar osteotomy for lengthening, realignment and } \\
\text { gradual reduction of CRHD and Illizarov external } \\
\text { fixation }(n=15)\end{array}$ & 13 & 13 & 2 & 2 & - & - \\
\hline TOTAL (patients of the main group, $n=33$ ) & $29(87.9 \%)$ & $29(87.9 \%)$ & $4(12.1 \%)$ & $4(12.1 \%)$ & - & - \\
\hline
\end{tabular}

Outcomes of the main group were rated as good in $100 \%$ of the cases with none of poor results. Fair results in the main group $(12.1 \%)$ were mostly associated with limited elbow function seen in patients who sustained injury more than one year ago, developed deformed and enlarged radial head and experienced restrictions in elbow flexion, extension and rotation after surgery. A comparative analysis of short- and long-term outcomes in both groups showed that the percentage of good results in the main group was 1.5 times higher than in the control group.
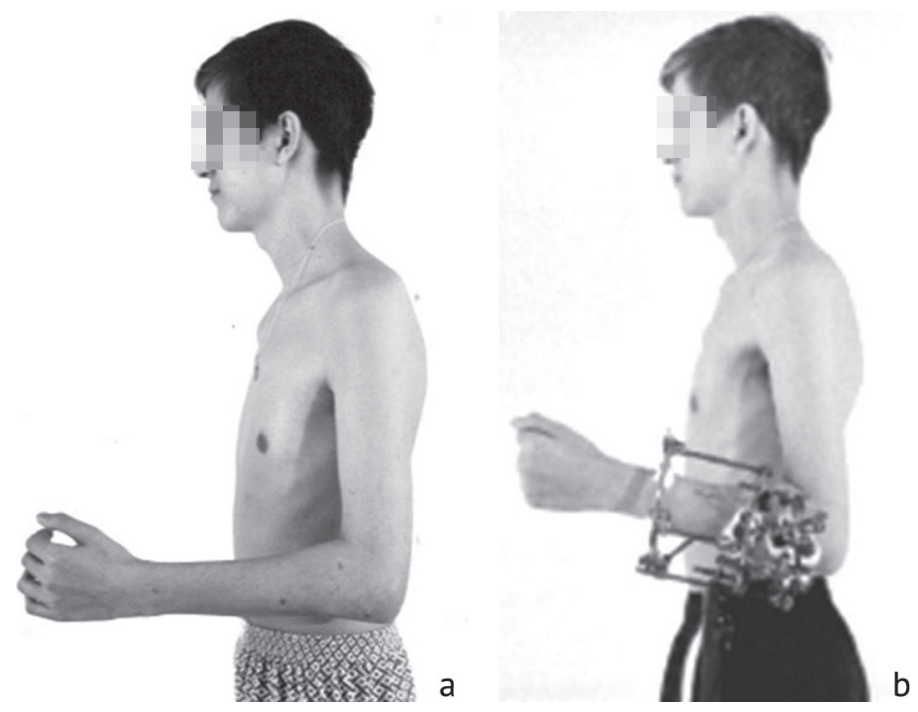

Case report A 17-year-old patient M. (Fig. 3, 4) received treatment for chronic anterior medial dislocation of the radial head, malunited fracture of the proximal ulna, flexion-extension contracture of the left elbow joint. He sustained an injury 18 months ago. He presented with preoperative flexion of $85^{\circ}$ and flexion of $140^{\circ}$. Ulnar osteotomy was produced for the patient and fixed with Ilizarov frame to allow realignment of the proximal ulna and bone lengthening. The radial head was ultimately reduced, ulna realigned and elbow function restored with a good outcome scored 20.

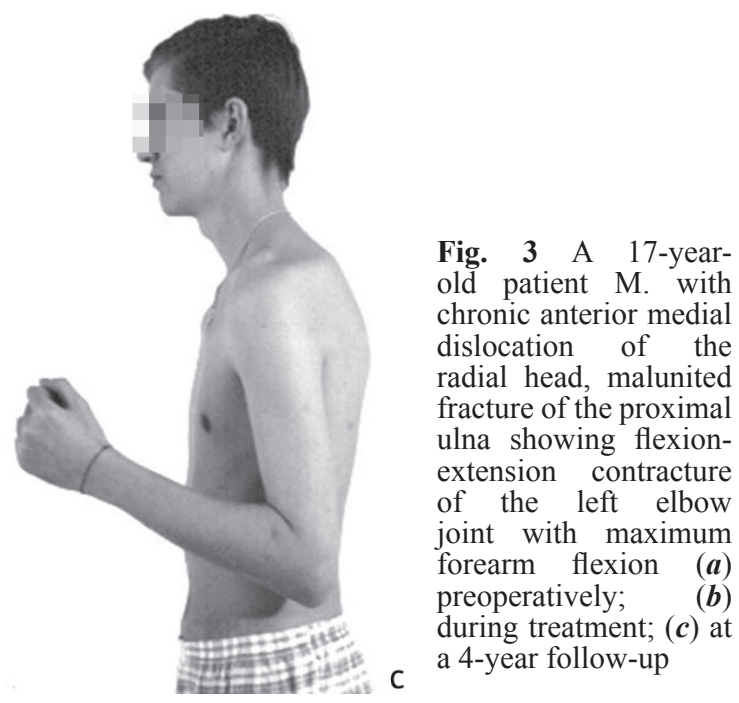



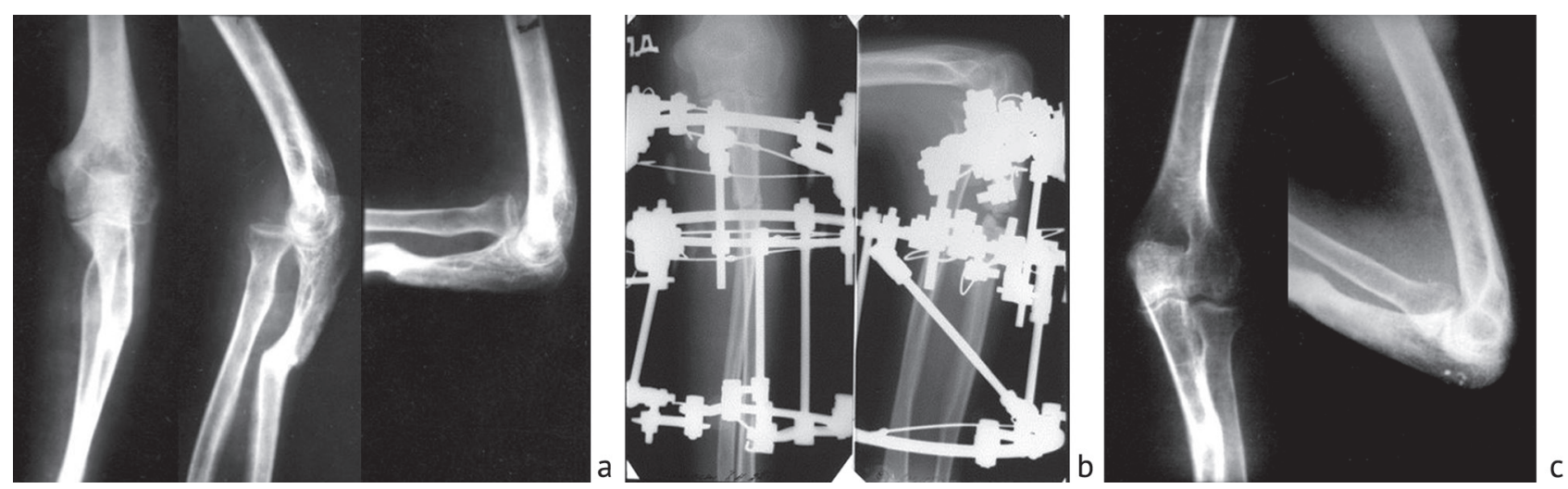

Fig. 4 Radiographs of the elbow joint of the 17-year-old patient M. with chronic anterior medial dislocation of the radial head, malunited fracture of the proximal ulna showing flexion-extension contracture of the left elbow joint showing $(\boldsymbol{a})$ preoperative anteroposterior and lateral views; $(\boldsymbol{b})$ with frame on; (c) AP and lateral views at a 4-year follow-up with maximum elbow flexion

\section{DISCUSSION}

The findings revealed that the clinical features of acute isolated radial head dislocations in children included poorly impaired elbow function of the joint, the absence of a forced arm position and absence of pain. This was the most common reason for delayed visits to pediatric orthopaedic surgeons [16-18]. The radial head dislocation tends to exacerbate over time, during bone development and growth with resultant deformation of different severity and shortening. The time from injury to definitive care and patient's age play a crucial role. These led to the search for new practical solutions to improve long-term outcomes and achieve ful recovery of the impaired limb functions in children.

S.S. Salnikov and Yu.P. Goltsov [19] suggested ulnar osteotomy to be performed at the apex of the deformity for bone lengthening, overcorrection at the coronal plane to allow bringing the radial head down simultaneously with closed reduction as an option for the treatment of CRHD patients and neglected ulnar fractures. Gradual ulnar lengthening and radial head reduction using the Ilizarov external fixation was reported by Ph. Gicquel et al. [20]. However, L. Wattincourt and R. Seringe [21], reported complications after surgical reduction of CRHD combined with ulnar osteotomy in the form of a recurrence and ulnar nonunion. The time from injury to surgery and patient's age were shown to be essential for optimum outcome.

As a result of our research, we modified the technique of surgical treatment of CRHD patients. ORRH, plasty of the annular ligament with $\mathrm{m}$. anconeus flap and one-month fixation with the plaster cast were performed for 18 cases of the main group. Four of 18 patients who had proximal ulna deformity and a hardly reducible radial head underwent additional ulnar osteotomy fixed with wires for deformity correction. It should be noted that the immobilization period in the main group was much shorter, and rehabilitation was initiated much earlier than in control group, with positive impact assessment. Based on the outcomes, a table of differentiated indications for the treatment of CRHD patients was developed (Table 3) with speculative purposes. The surgical option would rely on physical examination and radiological manifestations of the case.

Recurrence was shown to be caused by 1) ulnar deformity resulting form the Monteggia fracture; 2) ulnar shortening and deformity of the radial head developing during bone growth with the RHD being unreduced. Therefore, the anatomical and morphological changes developed in the elbow joint required realignment of the forearm bones and the elbow joint to ensure stabilization of the reduced radial head. These pathogenetic principles were consistent with the literature data [5]. The radial head was stabilized with the connective tissue formed at the radioulnar articulation due to realigned ulna (possibly with overcorrection) through closed gradual reduction of the radial head using ulnar lengthening and correcting osteotomy and the Ilizarov external fixation in the treatment of CRHD patients. The newly formed connective tissue did not interfere with the pronation of the forearm due to stretching rotational exercises of the forearm encouraged in the patients that were reported earlier [22]. 
Indications to surgical treatment of CRHD patients

\begin{tabular}{|c|c|c|c|}
\hline $\begin{array}{c}\text { Duration of the } \\
\text { disease }\end{array}$ & Age & $\begin{array}{c}\text { Anatomical and radiological } \\
\text { characterization }\end{array}$ & Surgical modality used \\
\hline Up to 2 months & - & $\begin{array}{l}\text { Neither ulnar shortening nor deformity } \\
\text { of the radial head }\end{array}$ & ORRH, plasty of the annular ligament \\
\hline \multirow[b]{2}{*}{$2-12$ months } & $\begin{array}{l}\text { Off the period of } \\
\text { active skeletal } \\
\text { growth }\end{array}$ & $\begin{array}{l}\text { Neither ulnar shortening nor deformity } \\
\text { of the radial head }\end{array}$ & ORRH, plasty of the annular ligament \\
\hline & $\begin{array}{l}\text { active skeletal } \\
\text { growth periods }\end{array}$ & $\begin{array}{l}\text { Ulnar shortening and deformity of the } \\
\text { radial head }\end{array}$ & $\begin{array}{l}\text { ORRH, plasty of the annular ligament with m. } \\
\text { anconeus flap, fixation of the radial head with } \\
\text { transarticular wire, oblique proximal ulnar } \\
\text { osteotomy and wire fixation }\end{array}$ \\
\hline \multirow{3}{*}{$\begin{array}{l}\text { More than } \\
12 \text { months }\end{array}$} & \multirow[b]{2}{*}{ Up to 14 years } & $\begin{array}{l}\text { Neither ulnar shortening nor deformity } \\
\text { of the radial head }\end{array}$ & $\begin{array}{l}\text { ORRH, plasty of the annular ligament with } \mathrm{m} \text {. } \\
\text { anconeus flap and fixation with the plaster cast }\end{array}$ \\
\hline & & $\begin{array}{l}\text { Ulnar shortening and deformity of the } \\
\text { radial head }\end{array}$ & $\begin{array}{l}\text { ORRH, plasty of the annular ligament with } \mathrm{m} \text {. } \\
\text { anconeus flap, fixation of the radial head with } \\
\text { transarticular wire, oblique proximal ulnar } \\
\text { osteotomy and wire fixation }\end{array}$ \\
\hline & $14-16$ years & $\begin{array}{l}\text { Ulnar shortening and deformity of the } \\
\text { radial head }\end{array}$ & $\begin{array}{l}\text { Ulnar osteotomy for lengthening, realignment and } \\
\text { gradual reduction of CRHD and Ilizarov external } \\
\text { fixation }\end{array}$ \\
\hline
\end{tabular}

\section{CONCLUSION}

Biomechanical articular parameters appear to from injury to surgery, patient's age, anatomical and deteriorate over time following radial head dislocation radiological manifestations of the joint. Operative and can result in radial head deformity, malaligned pediatric treatment of CRHD involving bone and and shortened ulna and radius. Pediatric treatment plasty procedures can provide good internal fixation is supposed to be differentiated depending on time preventing recurrence.

\section{REFERENCES}

1. Clare D.J., Corley F.G., Wirth M.A. Ipsilateral combination Monteggia and Galeazzi injuries in an adult patient: a case report. J. Orthop. Trauma, 2002, vol. 16, no. 2, pp. 130-134. DOI: 10.1097/00005131-200202000-00011

2. Dultsev I.A. Operativnoe lechenie zastarelykh vyvikhov i perelomo-vyvikhov v loktevom sustave. Avtoref. dis. ... kand. med. nauk [Surgical treatment of long-standing dislocations and fracture-disloations in the elbow. Cand. med. sci. diss. abstr.]. SPb., 2010, 26 p. (in Russian)

3. Korolev S.B., Pavlov D.B. Diagnostika i lechenie perelomo-vyvikhov tipa Montedzha: posobie dlia vrachei [Diagnosis and treatment of Monteggia type fracture-dislocations: manual for physicians]. N. Novgorod, 1998, 31 p. (in Russian)

4. Laratta J.L., Yoon R.S., Frank M.A., Koury K., Donegan D.J., Liporace F.A. Divergent elbow dislocation with radial shaft fracture, distal ulnar deformation and distal radioulnar joint instability: an unclassifiable Monteggia variant. J. Orthop. Traumatol., 2014, vol. 15, no. 1, pp. 63-67. DOI: $10.1007 / \mathrm{s} 10195-013-0239-\mathrm{X}$

5. Andreev P.S., Skvortsov A.P., Tsoi I.V. Khirurgicheskoe lechenie zastarelogo pereloma Montedzha u detei i podrostkov [Surgical treatment of long-standing Monteggia fracture in children and adolescents]. Prakticheskaia Meditsina, 2014, no. 4-2: Innovatsionnye Tekhnologii v Meditsine, pp. 19-22. (in Russian)

6. Ovsiankin N.A. Lechenie posledstvii travm loktevogo sustava u detei: aktovaia rech [Treatment of the consequences of the elbow injuries in children: act speech]. Nauch.-issled. Det. Ortoped. In-t im. G.I. Turnera. SPb., 2000, 21 p. (in Russian)

7. Datta T., Chatterjee N., Pal A.K., Das S.K. Evaluation of outcome of corrective ulnar osteotomy with bone grafting and annular ligament reconstruction in neglected Monteggia fracture dislocation in children. J. Clin. Diagn. Res., 2014, vol. 8, no. 6, pp. LC01-LC04. DOI: 10.7860/ JCDR/2014/9891.4409

8. Tan J., Mu M., Liao G., Zhao Y., Li J. Biomechanical analysis of the annular ligament in Monteggia fractures using finite element models. J. Orthop. Surg. Res., 2015, vol. 10, pp. 30. DOI: 10.1186/s13018-015-0170-3.

9. Ovsiankin N.A., Kazimirskii V.E., compilers. Operativnoe lechenie detei s posttravmaticheskimi vyvikhami predplechia v loktevom sustave: metod. rekomendatsii [Surgical treatment of children with posttraumatic forearm dislocations in the elbow: guidelines]. Leningr. Nauch.-issled. Det. Ortoped. In-t. L., 1988, 17 p. (in Russian)

10. Proshchenko Ia.N., Ovsiankin N.A., Pozdeeva N.A. Metody lecheniia detei s travmami oblasti loktevogo sustava (obzor literatury) [Methods of treating children with the elbow injuries (review of the literature)]. Travmatologiia i Ortopediia Rossii, 2011, no. 4, pp. 147-151. (in Russian)

11. Cobanoglu M., Şavk Ş.O., Cullu E., Duygun F. Ipsilateral supracondylar humerus fracture and Monteggia lesion with a 5-year follow-up: a rare injury in a young girl. BMJ Case Rep., 2015, vol. 2015, pp. bcr2014206313. DOI: 10.1136/bcr-2014-206313

12. Babovnikov A.V. Novyi sposob khirurgicheskogo lecheniia zastarelykh vyvikhov predplechia [A new method for the surgical treatment of long-standing forearm dislocations]. Materialy mezhdunar. iubil. nauch.-prakt. konf., posviashch. 200-letiiu so dnia rozhdeniia N.I. Pirogova "Sovremennye povrezhdeniia $i$ ikh lechenie" [Proceedings of the International Anniversary Scientific-practical conference, devoted to $200^{\text {th }}$ anniversary of N.I. Pirogov's birth "Modern Injuries and their Treatment”]. Moscow, 2010, pp. 44-45. (in Russian)

13. Salnikov S.S., Goltsov Iu.A. Sposob lecheniia zastarelogo pereloma loktevoi kosti s vyvikhom golovki luchevoi kosti [The way of treating the longstanding ulnar fracture with radial head dislocation]. Patent RF no. 2012258, A 61B 17/56, 1989. (in Russian)

14. Kalamchi A. Monteggia fracture-dislocation in children. Late treatment in two cases. J. Bone Joint Surg. Am., 1986, vol. 68, no. 4, pp. 615-619.

15. Shevtsov V.I., Shved S.I., Sysenko Iu.M. Chreskostnyi osteosintez pri lechenii oskolchatykh perelomov [Transosseous osteosynthesis in the treatment of comminuted fractures]. Kurgan, 2002, 332 p. (in Russian)

16. Eamsobhana P., Kaewpornsawan K. Chronic Monteggia lesions treatment with open reduction and Z-lengthening technique with annular ligament reconstruction. J. Med. Assoc. Thai., 2012, vol. 95, no. Suppl. 9, pp. S47-S53.

17. Horii E., Nakamura R., Koh S., Inagaki H., Yajima H., Nakao E. Surgical treatment for chronic radial head dislocation. J. Bone Joint Surg. Am., 2002, vol. 84, no. 7, pp. 1183-1188. DOI: 10.2106/00004623-200207000-00014 
18. Di Gennaro G.L., Martinelli A., Bettuzzi C., Antonioli D., Rotini R. Outcomes after surgical treatment of missed Monteggia fractures in children. Musculoscelet. Surg., 2015, vol. 99, no. Suppl. 1, pp. S75-S82. DOI: 10.1007/s12306-015-0362-3.

19. Gicquel P., De Billy B., Karger C., Maximin M.C., Clavert J.M. Traitement de la fracture de Monteggia negligee par allongement de l'ulna avec la technique d'Ilizarov [Treatment of neglected Monteggia's fracture by ulnar lengthening using the Ilizarov technique]. Rev. Chir. Orthop. Reparatrice Appar. Mot., 2000, vol. 86, no. 8, pp. 844-847. (in French)

20. Wattincourt L., Seringe R. Fractures de Monteggia anciennes chez 1,enfant. Treitement chirurgical: resultats a moyen terme [Old Monteggia fractures in a child. Surgical treatment: results in medium terms]. Chir. Orthop., 2000, vol. 86, no. suppl. II, pp. 39. (in French)

21. Soldatov Iu.P., Makushin V.D. Apparat Ilizarova. Lechenie patologii loktevogo sustava s pozitsii dokazatelnoi meditsiny [The Ilizarov fixator. Treatment of elbow pathology from the standpoint of evidence-based medicine]. Germany, Saarbrücken, LAP LAMBERT Academic Publishing, 2016.301 p. (in Russian)

Received: 17.03 .2020

\section{Information about the authors:}

1. Iskandar Yu. Khodzhanov, M.D., Ph.D., Professor,

Republican Specialized Scientific and Practical Medical Center of Traumatology and Orthopedics, Tashkent, Uzbekistan

2. Yuri P. Soldatov, M.D., Ph.D., Professor,

Ilizarov National Medical Research Centre for Traumatology and Orthopedics, Kurgan, Russian Federation,

Email: soldatov-up@mail.ru

3. Gairat Dz. Baiimbetov, M.D., Ph.D.,

Republican Specialized Scientific and Practical Medical Center of Traumatology and Orthopedics, Tashkent, Uzbekistan

4. Umid A. Edilov, M.D.,

Republican Specialized Scientific and Practical Medical Center of Traumatology and Orthopedics, Tashkent, Uzbekistan 